\title{
To Enhance the Fire Resistance Performance of High-Speed Steel Roller Door with Water Film System
}

\author{
De-Hua Chung, ${ }^{1}$ Tien-Chih Wang, ${ }^{2}$ Ming-Ju Tsai, ${ }^{2}$ Ta-Hui Lin, ${ }^{1}$ and Shin-Ku Lee \\ ${ }^{1}$ Research Center for Energy Technology and Strategy, National Cheng Kung University, Tainan 701, Taiwan \\ ${ }^{2}$ Architecture and Building Research Institute, Ministry of the Interior, New Taipei City 231, Taiwan \\ Correspondence should be addressed to Shin-Ku Lee; sklee1015@gmail.com
}

Received 1 May 2015; Revised 13 July 2015; Accepted 14 July 2015

Academic Editor: Antônio G. B. de Lima

Copyright (C) 2015 De-Hua Chung et al. This is an open access article distributed under the Creative Commons Attribution License, which permits unrestricted use, distribution, and reproduction in any medium, provided the original work is properly cited.

\begin{abstract}
The structure of high-speed roller door with water film has improved in this study. The flameproof water film system is equipped with a water circulating device to reduce the water consumption of water film system. The water film is generated at the roller box of the high-speed roller door in this study. The heating test is done with the full-scale heating furnace. Both cases of the water film on unexposed surface and water film on exposed surface passed the fire resistance test based on ISO 834, proving that the high-speed roller door with water film system has 120A fire resistance period. The main findings indicate that the water film on exposed surface shows that as the amount of water film evaporated by high temperature inside the furnace must be greater than the evaporation capacity of water film on unexposed surface, the required water supply is $660 \mathrm{~L}$ more than the water film on unexposed surface.
\end{abstract}

\section{Introduction}

Taiwan is a region with constant typhoons and earthquakes, as well as high temperature and high humidity [1]. Nearly 15 years ago, there were 6.2 typhoon warnings per year in Taiwan [2]. Thus, the buildings often use metal doors considering the durability and safety, such as sliding doors, grilles, and roller shutters. The roller door is retractable, occupying less space, so it accounts for the largest proportion. The roller doors include traditional roller door and high-speed roller door. The shutters of traditional roller door are heavier. The traditional roller door usually rolls slowly (lifting speed is lower than $5 \mathrm{~m} / \mathrm{min}$ ), and the noise is loud for the friction of actuation between the roller shutters and guide rails. Because the electrical load of operation is higher, the barrel spring mechanism is prone to elastic fatigue. Therefore, the high-speed roller door is developed to overcome the above problems. It is characterized by faster opening/closing (lifting speed is higher than $10 \mathrm{~m} / \mathrm{min}$ ), better airtightness, less noise, high wind resistance, and energy saving, so the high-speed roller door is being used in buildings extensively.

Furthermore, numerous high-rise buildings have been constructed in recent years, and the number of stories and area of buildings are increased significantly, especially large marketplaces and exhibition complexes. In accordance with the Building Technical Rules of Taiwan [3], if the building floor area is over $1500 \mathrm{~m}^{2}$, the building should be separated into isolated fire compartments by fireproof walls, doors, or windows that have a fire resistance rating of at least 1 hour. From the commercial side, the higher the visibility of goods, the higher the sales volume. Thus, movable fire compartments, such as fireproof roller shutters, are popular with the higher visibility of goods, instead of the solid walls. In order to maintain the original functions in buildings, many designers prefer to choose fireproof roller shutters rather than fixed fireproof walls.

The fireproof roller doors are mostly made of steel for retractability. If it is not resistant to heat, there is a great deal of thermal radiation after fires, which is hazardous [4]. At present, the traditional steel roller door is the majority in Taiwan's roller door market, accounting for about $60 \%$, and the rest of $40 \%$ is high-speed roller door. Under the requirement of fire prevention code, the roller doors with 1hour fire endurance are the majority, $60 \mathrm{~B}$ (with 60-minute fire endurance but without thermal resistance) traditional roller door accounts for $25 \%$, and $60 \mathrm{~A}$ (60-minute fire endurance 
and thermal resistance) traditional roller door accounts for $25 \%$. However, the high-speed roller door must keep fast lifting speed (larger than $10 \mathrm{~m} / \mathrm{min}$ ), so it has no fire retardant in the existing market.

There are three common heat resisting techniques of fireproof roller doors: (1) the roller shutters coated with heatresistant paint; (2) fire protection stuffing; and (3) water system, for example, water mist. The former two techniques can reach 60A specified by CNS 14803 [5], but once the burning duration exceeds 60 minutes, the thermal resistance declines. In addition, the cost of the roller door coated with heat-resistant paint is higher than general $60 \mathrm{~B}$ by about 5 times. The shutters with fire protection stuffing are too heavy and too thick, which decreases the lifting speed. Therefore, the application of water system to the high-speed roller door to enhance the fire endurance and thermal resistance of highspeed roller door shall be further studied.

When the water meets high temperature at the fire scene, water droplets form, evaporate, and fill with the overall space rapidly. Therefore, the fire scene temperature and heat radiation can be reduced by water, immediately. The concept of water system applied in fire compartment has been developed rapidly.

Aihara et al. [6] used a spray to form a water film on solid surfaces. The evaporation of the water film takes away heat and lowers the surface temperature. The results in their researches indicated that water film provides a good cooling capability. Richardson and Oleszkiewicz [7] conducted fullscale fire tests with water spray. The results showed that over $90 \%$ of the thermal radiation to the glass was absorbed. These results indicated that water spray on solid surfaces is a good cooling solution. Nishio and Kim [8] applied a simple model to predict the heat flux distribution of a dilute spray impinging on the hot surface. Sozbir et al. [9] conducted experimental studies to reveal the heat transfer mechanism of impacting water mist on high temperature metal surfaces. The overall heat transfer coefficient can be established as two separable effects, which is the summation of the heat transfer coefficient of air and liquid mass flux. Cai et al. [10] performed experimental studies to determine the flow field and thermal radiation blockage of the water curtain. They indicated that the absorption and scattering of the incoming radiation were the two main mechanisms of radiation attenuation by the water curtain. Increases of the thickness of the water curtain, the operating pressure, and the flow rate can be beneficial to the reduction of the radiation heat flux through the water curtain. The maximum efficiency of radiation attenuation was approximately $80 \%$, but it was not linearly proportional to the thickness of the water curtain. Wu et al. [11] designed a small-scale $(1.8 \mathrm{~m} \times 1.8 \mathrm{~m} \times 1.8 \mathrm{~m})$ apparatus to investigate the heat resistance property of the water spray on a glass pane. Water of $37.8 \mathrm{~L} / \mathrm{min}$ was sprayed on the exposed surface of the glass pane to form water film. Furthermore, Wu and Lin [12] examined the fire insulation and fire integrity of glass panes with a downflowing water film in a standard full-scale $3 \mathrm{~m} \times 3 \mathrm{~m}$ door/wall refractory furnace, which is based on ISO 834-1. The experimental results $[11,12]$ showed that the period of fire insulation and fire integrity for a non-heatresistant fireproof glass and a common tempered glass can be extended from 6 to 100 minutes. And the temperatures on surface of the glass panes were kept below $210^{\circ} \mathrm{C}$ with a water film. These results proved the feasibility of replacing a fireproof glass by common tempered glass with a water film. The heat transfer due to the spray cooling of surfaces using full cone nozzles for a spray water mass flux $V_{S}$ in the range of $3-30 \mathrm{~kg} / \mathrm{m}^{2} \cdot \mathrm{s}$ and surface temperatures between 200 and $1100^{\circ} \mathrm{C}$ was investigated by Wendelstorf et al. [13]. They indicated that, in the stable film boiling regime, the heat transfer coefficient decreased with temperature difference $\Delta T$ above $800 \mathrm{~K}$ for $V_{S}>10 \mathrm{~kg} / \mathrm{m}^{2} \cdot \mathrm{s}$. Chen and Lee [14] applied the hybrid inverse scheme to solve a $2 \mathrm{D}$ transient inverse heat conduction problem with the temperature measurement data given by $\mathrm{Wu}$ et al. $[11,12]$ in order to estimate the unknown transient total heat flux and overall heat transfer coefficient on the hot surface of the glass pane with the downflowing water film exposed to a fire environment. Their estimated results [14] indicated that the evaporative latent heat dominated the total incident heat flux for the glass pane with the downflowing water film. The total incident heat flux decreased with increasing the water flow rate. The glass pane could effectively absorb the high heat rate and resist the radiation of the fire with the downflowing water film that could uniformly cover on the exposed fire surface of the glass pane with an appropriate water flow rate. Thus, the overall heat transfer coefficient on the exposed fire surface of the glass pane can approach asymptotically a constant value even though the temperature of the furnace keeps rising.

According to the above literatures survey, the cooling principle on solid surface with water system can be concluded as follows:

(i) Evaporative cooling [15]: the evaporation latent heat of water is $539 \mathrm{cal} / \mathrm{g}$. Therefore water absorbs a great deal of heat energy during extinguishment and reduces the temperature from fire source.

(ii) Surface area effect: the heat absorption rate of water droplets is proportional to surface area. When the drop size decreases to $10 \%$, the total surface area is increased by about 10 times, and the heat absorption efficiency is higher.

(iii) Heat convection effect [16]: the water spray droplets are small and light. The droplets are likely to be influenced by heat convection effect, and the floatation time of water droplets in the air can be prolonged. If the water droplets are led in the fire source, they enhance heat absorption by evaporation.

(iv) Thermal radiation blockage [17]: the penetrative marching speed of thermal radiation in water droplets and vapor is much lower than in dried air under the effect of refraction. Thermal energy is transmitted virtually blocked to prevent the spread of fire.

Although the characteristics of a water film on a roller shutter are different from those on a glass pane, the experimental and design experience of the glass pane with a water film can be transferred to a roller shutter with a water film because the basic mechanism of heat removal is the same. The combination of water system and roller shutter door 
was first found in Mainland China. For fire compartments, Chen et al. [18] equipped a common steel roller shutter with a water curtain cooling device for fire protection. They installed sidewall sprinklers on both sides or one side of the roller shutter (the distance between the sprinklers was 2$2.5 \mathrm{~m}$ ) to perform the fire test. From the experimental results, they proposed the following formula for the amount of used cooling water, $Q$ :

$$
Q= \begin{cases}0.5 L, & H<4 \mathrm{~m}, \\ {[0.5+(H-4) \times 0.1] L,} & 4 \mathrm{~m}<H<9 \mathrm{~m}, \\ 1.0 L, & H>9 \mathrm{~m},\end{cases}
$$

where $L$ and $H$ are, respectively, the length and height of the roller shutter.

Liu et al. [19] discussed the effect of the aforesaid design parameters on the fireproof roller door with water-mist system and proposed probable variables, including the pressure inside water supply pipe, nozzle horizontal distance, and nozzle-shutter spacing. The findings indicate that the nozzle horizontal distance is the primary influencing factor, and the nozzle pressure is the secondary influencing factor. The distance between nozzle and shutter is general influencing factor. The findings showed that (1) the average spray quantity decreases as the nozzle horizontal distance increases; (2) the average spray quantity increases with the nozzle-shutter spacing; and (3) the average spray quantity increases with the nozzle pressure. Liu et al. [19] further developed a new type of nozzle, rotary water spray nozzle. The high-velocity flow of water is divided into several straight and rotating jets. The jets impact and smash each other when flowing through the small nozzle, jetting out of the nozzle as fine droplets and fog. As the total surface area of water droplet is enlarged, the heat absorption and evaporation are fast, and the cooling effect on the roller shutter surface is better. Feng et al. [20] developed a water-fog fireproof roller door with the wetting system to enhance the heat resistance of iron roller. For the heat resistance of $3.2 \mathrm{~m}$ wide roller door, it needed two common sprinkler nozzles to cover the door surface. The total water flux was $1 \mathrm{~L} /\left(\mathrm{s}-\mathrm{m}^{2}\right)$, which was $0.5 \mathrm{~L} /\left(\mathrm{s}-\mathrm{m}^{2}\right)$ for one nozzle. However, the water flux of the water-fog fireproof roller shutter used only $0.25 \mathrm{~L} /\left(\mathrm{s}-\mathrm{m}^{2}\right)$, which was only $25 \%$ of common sprinkler head fireproof roller shutter.

Lin [21] tested the heat resistance of the combination of water film system and roller door with the full-scale experiment. They tried to offer the water film by three ways: fire sprinkler, water mist sprinkler, and perforated pipe in the cold flow field experiment. Only the perforated pipe offered a water film because the water in a trough spilled over and covered the surface of roller shutter. The jets of fire sprinkler and water mist sprinkler were difficult to produce a water film. The back temperature of nonheating surface remained lower than $100^{\circ} \mathrm{C}$ as the furnace temperature rises, whether the water film faced the burners or not. However, the water evaporation for water film inside the furnace was increased by about $10 \mathrm{~L} / \mathrm{min}$ compared with that outside the furnace.

In the present study, we extend our findings of the previous evaluations to design a water film cooling system with water circulating device to enhance the heat resistance of a traditional high-speed roller door without fire resistance rating and further justify the thermal performance and water consumption amount of the water film on the high-speed roller door.

\section{Experimental Apparatus and Method}

In this study, full-scale door/wall refractory tests are conducted to investigate the heat resistance performance of a generalized roller shutter without heat resistance but incorporated with a downflowing water film.

2.1. Full-Scale Heating Furnace. Figure 1(a) shows a photograph of the full-scale door/wall refractory furnace, which provides the standard temperature heating curve for the heat resistance experiment. The construction and function of the full-scale furnace are in accordance with ISO 834, CNS 14803, and ISO 3008 for thermal resistance experiments of fireproof doors (wood doors, steel roller shutters, etc.). The inner and outer dimensions of the furnace are $430(W) \times 450(H) \times$ $100(L) \mathrm{cm}$ and $500(W) \times 520(H) \times 140(L) \mathrm{cm}$, respectively. The available testing area, that is, the area directly exposed to the furnace fire, and the maximum testing duration are $400(W) \times 400(H) \mathrm{cm}$ and 4 hours, respectively.

Steel structures used on the exterior of the furnace include the test frame, air supply device, exhaust duct, and hood. The surfaces inside the furnace are covered with fireproof ceramic fiber capable of enduring temperatures of over $1400^{\circ} \mathrm{C}$. The burning system contains flat-flame liquefied petroleum gas (LPG) burners, which are equipped with UV flame sensors to monitor the flame state. The burner generates a flat yellow diffusion flame, and thus radiation and convection are the primary and secondary modes of heat transfer inside the furnace, respectively.

Figure 1(b) shows the positions of the burners and thermocouples in the furnace. As can be seen, seventeen flatflame burners (shown as 9 ) are set in five rows from top to bottom and sixteen thermocouples (shown as (2)) are used to monitor and record variations of the temperature distribution. Four additional feedback temperature control sensors (shown as are installed to control the furnace temperature to follow the ISO or CNS standard temperature curve. The CNS 14803 standard requires that the testing surface area be the actual size of the roller shutter or not larger than $3 \mathrm{~m} \times 3 \mathrm{~m}$.

2.2. Setup and Measurements. To fully understand the water film performance on the shutter slat surface, $25 \mathrm{~K}$-type thermocouples were installed on the cold surface of shutter slats. Figure 2(a) shows the temperature measurement positions, and Figure 2(b) shows the schematic of the unexposed surface in a fire test. As can be seen, the shutter slat surface is divided into five vertical sections at different heights denoted by $a \sim e$ from top to bottom and numbered 1 5 from right to left. In Figure 2(a), the red circles indicate the required measurement positions for CNS 14803 . Note that $c 1$ and $c 5$ must be set on the guide rail, while the other thermocouples are to be set on the shutter slat surface. In addition, to evaluate 

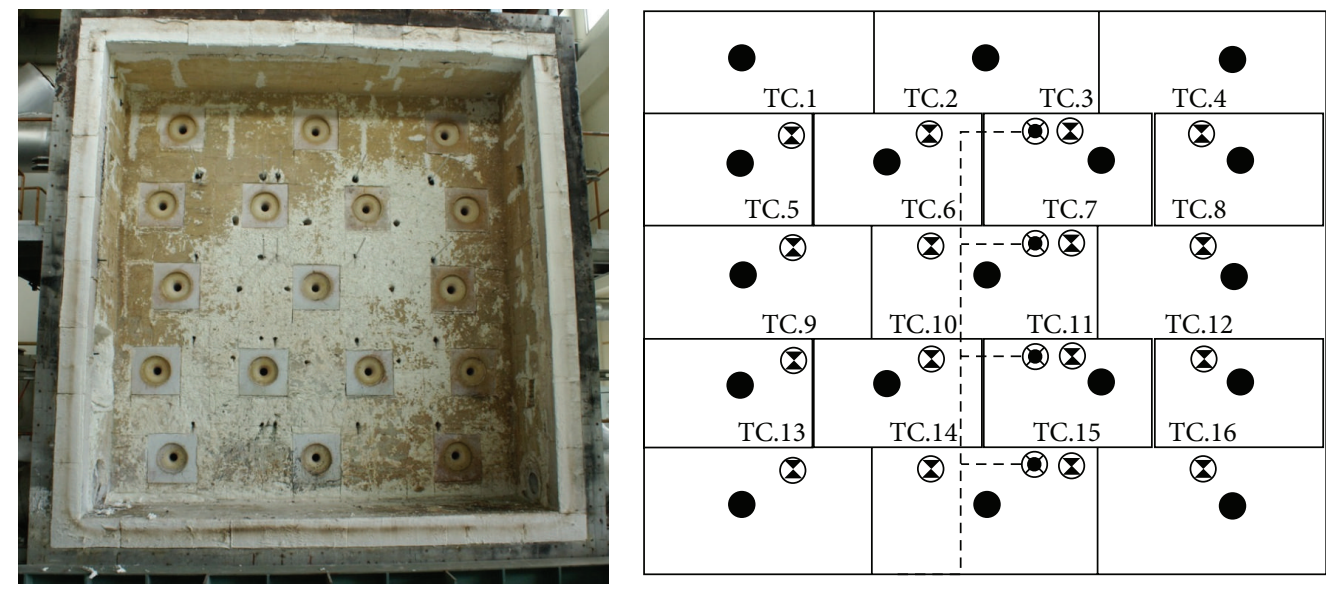

Burners

(2) Temperature control sensors

(2) Temperature record sensors

(a)

(b)

Figure 1: (a) Full-scale heating furnace; (b) positions of thermocouples inside the full-scale heating furnace.

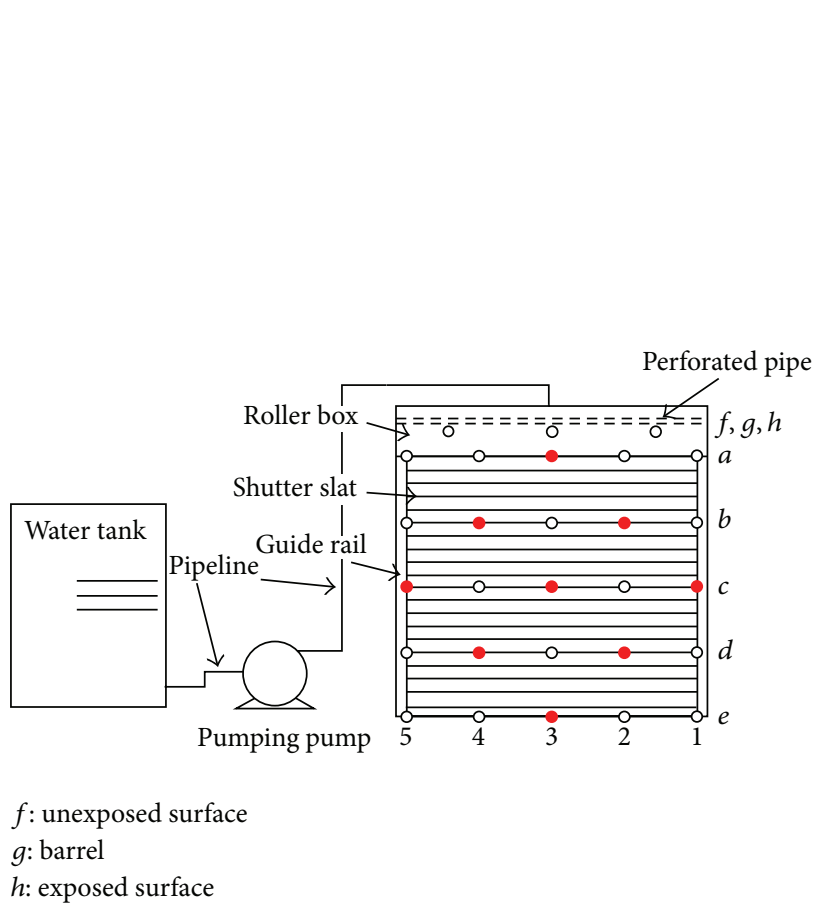

(a)

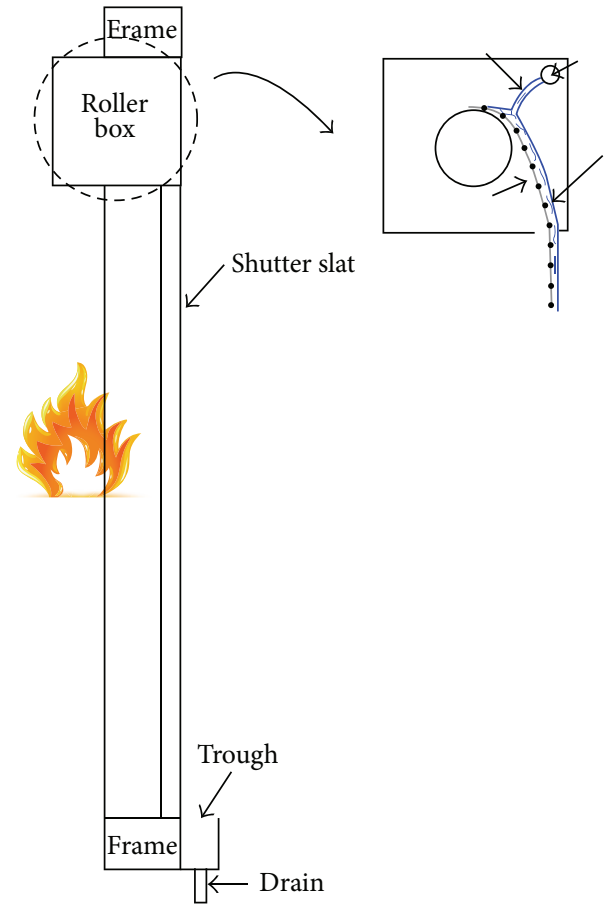

(b)

FIGURE 2: (a) Test frame with roller shutter and temperature measurement positions on the roller shutter; (b) schematic of the unexposed surface in a fire test.

the control of the roller box internal temperature by the proposed design, three positions of three thermocouples at $100 \mathrm{~cm}$ intervals were installed on the cold surface of roller box $(f 1 \sim f 3)$, on the roller barrel $(g 1 \sim g 3)$, and on the hot surface of the roller box $(h 1 \sim h 3)$, respectively. The error range of the K-type thermocouples is $\pm 0.4 \%$ [22], while their temperature histories are recorded and used to evaluate the heat-resistant performance of the proposed system.

2.3. Water Film System Design. At present, the fireproof roller door or glass on the market is more expensive than those without fireproof performance for addition of special 


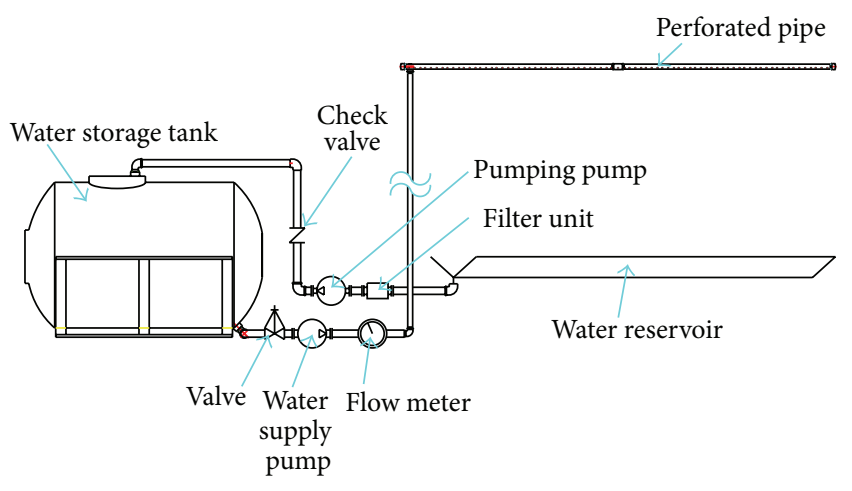

FIgURE 3: Water circulating device.

coating or materials. "Flameproof water-flow producer" [23] and "multihollowed pipe water film generation device for flameproof" [24] can form a water film by spraying to retard the flame. If the water sprayed out of this type of device can be recycled, the water resource will not be wasted. In the region short of water source, if the water sprayed can be recovered, the fireproofing will not be influenced even if there is no water supply, and the overall structure design has watersaving and safe practicability. In addition, the flameproof water film system implemented in the existing buildings will be free from the pipelines of fire water tanks, as long as it is connected to the water storage tank; the flameproof water film system can be operated by the water circulating device.

The water circulating device of the fireproof water film system designed in this study is shown in Figure 3. The water film system has a water storage tank, the outlet of the water storage tank is connected to a water supply pump, the water supply pump is connected to perforated pipe, and the inlet of water storage tank is connected to a pumping pump, the perforated pipe corresponding to the pumping pump is connected to a water reservoir, and there is a filter unit between the pumping pump and water reservoir. Therefore, the water supply pump pumps the water from the water storage tank to the perforated pipe, and the water is sprayed through the holes of perforated pipe to form water film. The water flows downward into the water reservoir. The water in the water reservoir is filtered by the filter unit and pumped by the pumping pump into the water storage tank for recycling.

2.4. Test Frame of Rolling Door. Figures 4 and 5 show the front and side views of test frame with the roller shutter installed. The test surface area, including the roller box, guide rail, and shutter slats, is $3 \mathrm{~m} \times 3 \mathrm{~m}$, while the height and width of the roller box are $43 \mathrm{~cm}$ and $63 \mathrm{~cm}$, respectively. The width of the guide rail is $7 \mathrm{~cm}$ and the thickness of the shutter slat is $1.5 \mathrm{~mm}$. The roller shutters and roller box do not have fireproof performance.

In addition to the temperature measurement, a water reservoir was installed to further characterize the heatresistant performance of the proposed system. The water reservoir was installed below the rolling door to collect the remaining water from the shutter slat surface to investigate the relation between the evaporation of the water film and the heating rate from the furnace during the experiment, as shown in Figure 6. The volumetric flow rate of return water was measured by a water storage tank with the capacity of $100 \mathrm{~L}$ per minute. The minimum water consumption required for the proposed design to conform to the heat resistance requirement of CNS 14803 can then be estimated. The width of water reservoir was $2.9 \mathrm{~m}$, and the depth of water reservoir was $0.24 \mathrm{~m}$.

In this experiment, the water film system consisted of a water supply pump, two perforated steel pipes, and a piping system and was designed to form a downflowing water film that covers the surface of the roller shutter slats (Figure 7). For fire protection of a roller box surface, two perforated pipes are installed in the top corner of the roller box, allowing jets of water from the pipe to flow directly over the surface of the shutter slats and form a water film: one near the front side sprays at a $30^{\circ}$ depression angle on the front side of internal roller box surface and also spray at a $60^{\circ}$ depression angle on the shutter slats and the other pipe near the back side sprays at a $30^{\circ}$ depression angle on the back side of internal roller box surface (Figure 2(b)). Further, the baffle board is installed $50 \mathrm{~mm}$ away from the roller box surface on its bottom surface to create a small gap (trough) in the space between the roller box surfaces and baffle board, which can accumulate water spraying on the roller box surface from the perforated pipes and surround the barrel (Figure 8). The baffle board near the front side is slightly lower than the others. Thus, when the water in the gap accumulates upon the top edge of the frontside baffle board, the water overflows from the gap and falls upon the surface of the roller shutter slats, producing a water film with uniform thickness on the surface. However, the water jet flow rate varies due to different hole diameters and different jet velocities [25]. In this study, there are 75 holes along the 3-meter perforated pipe, with a spacing between each hole of $40 \mathrm{~mm}$. The diameters of the holes along the perforated pipe change in two steps. The first twenty holes from the end hole are $4 \mathrm{~mm}$ in diameter while the others are $4.1 \mathrm{~mm}$. Figure 3 shows a picture of this waterfilm system.

2.5. Testing Procedure. The perforated pipe is put in the roll box and "injected with water" to form water film on the surface of shutters, the full-scale experiment is conducted to investigate the heat resistance performance of high-speed roller door with water film system. According to CNS 14803 [5] specifications, both sides of specimen must be tested. Therefore, two experiments were tested: (1) water film on the fire-unexposed side and (2) water film on the fire-exposed side. The former one is called "water film on unexposed surface" and the latter one is called "water film on exposed surface."

\section{Results and Discussion}

3.1. Heat Resistance Enhancement of Water Film on Unexposed Surface. Figure 9 shows the time-varying curve of temperature inside furnace for this fire test along with the standard temperature curve of CNS 14803. According to the comparison between the curve of average temperature inside furnace and the standard heating temperature curve, from 55 


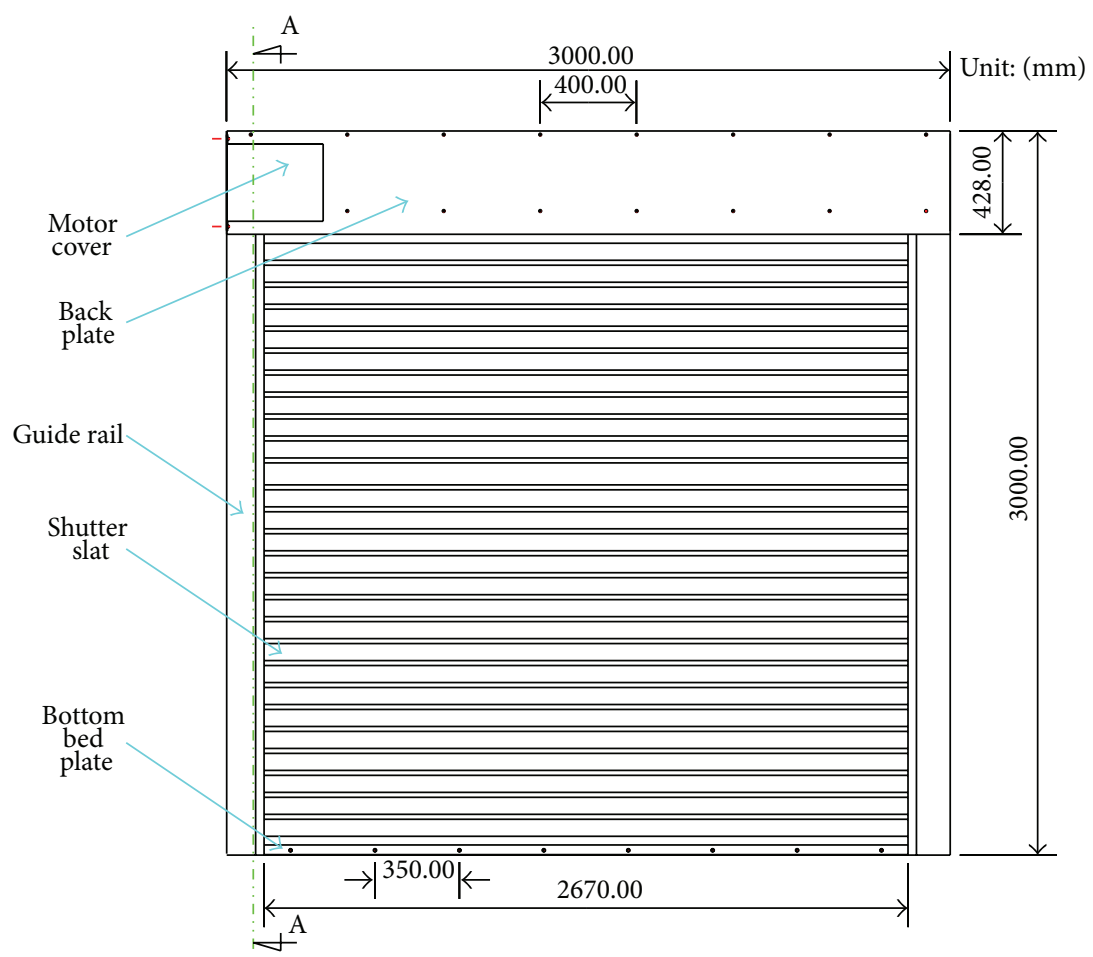

FIGURE 4: Front view of rolling door (face to roller box).

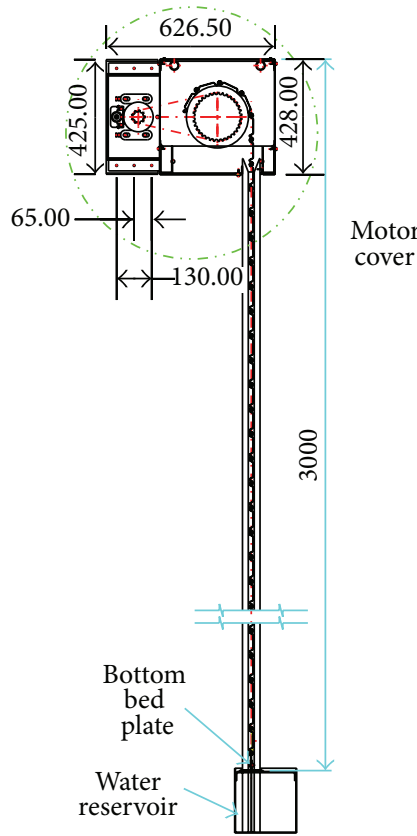

Unit: (mm)

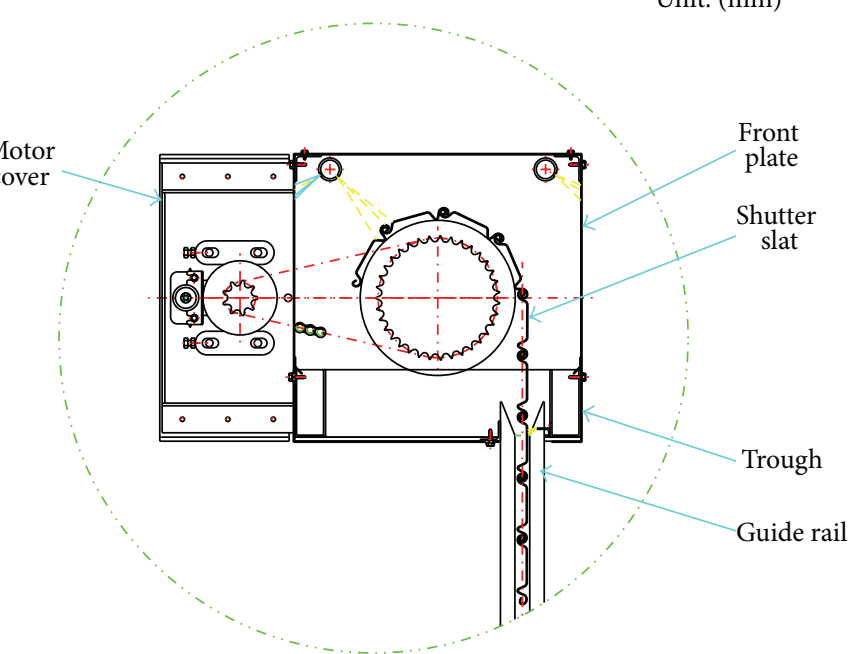

A-A cross section

FIgURE 5: Cross section along $\overline{\mathrm{AA}}$ in Figure 6.

minutes to 120 minutes of heating, the average temperature inside furnace is lower than the standard temperature curve value. However, the amount of deviation is within standard temperature $\pm 100^{\circ} \mathrm{C}$; the furnace temperature curve is still in the permissible range of CNS 14803.

Figure 10 presents the temperature variations of unexposed surface of shutter slat. The recorded temperature curves at all points of unexposed surface have oscillation, but as the furnace temperature (Figure 9) rises, the temperatures at all points basically rise. The average temperature shows that from the beginning of heating to 35 minutes, the unexposed surface temperature rises continuously; from 35 minutes of heating test to the end of experiment, the average temperature is kept at $100^{\circ} \mathrm{C}$. It shows that if the water film system can 


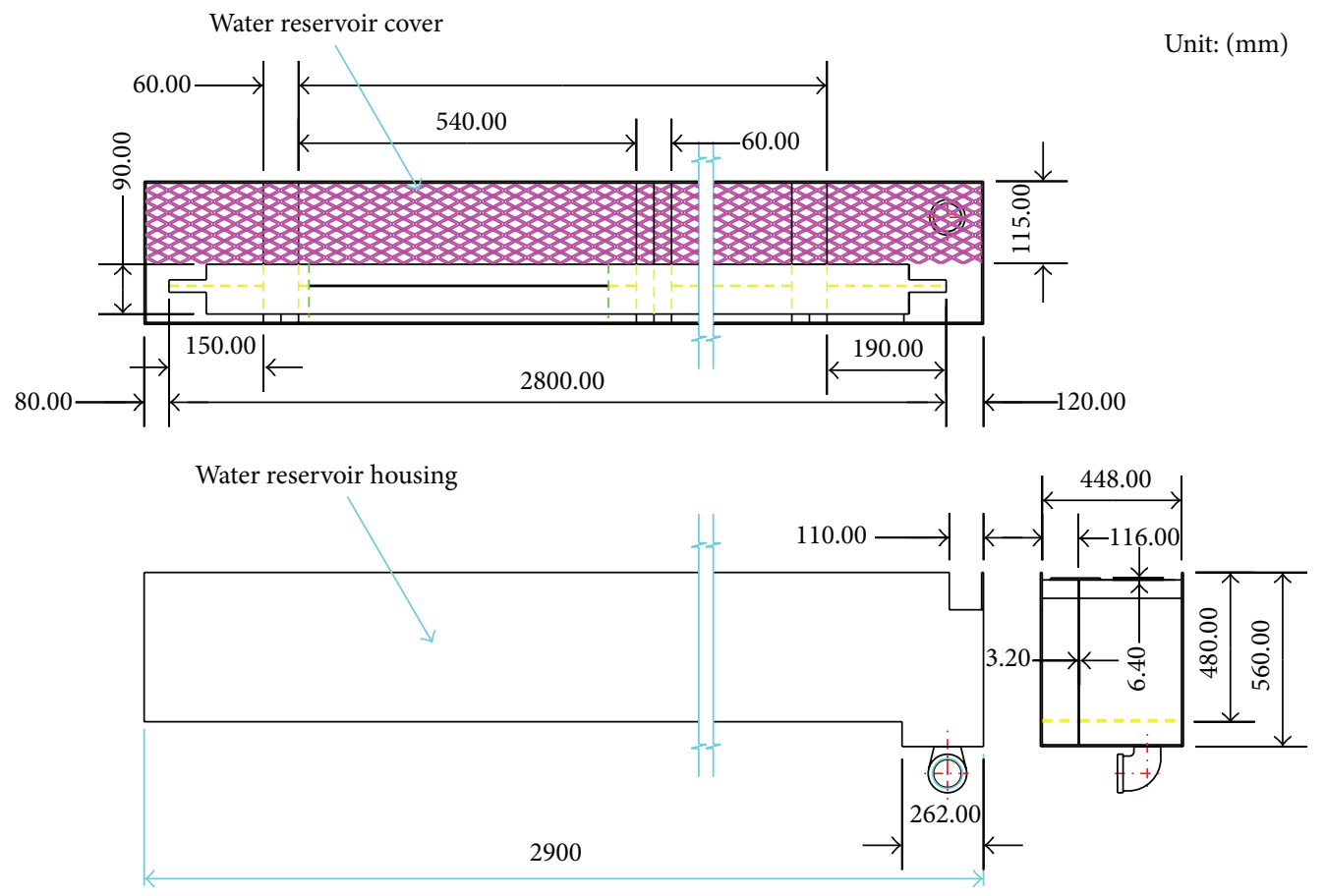

FIgURE 6: Water reservoir installed below the rolling door.

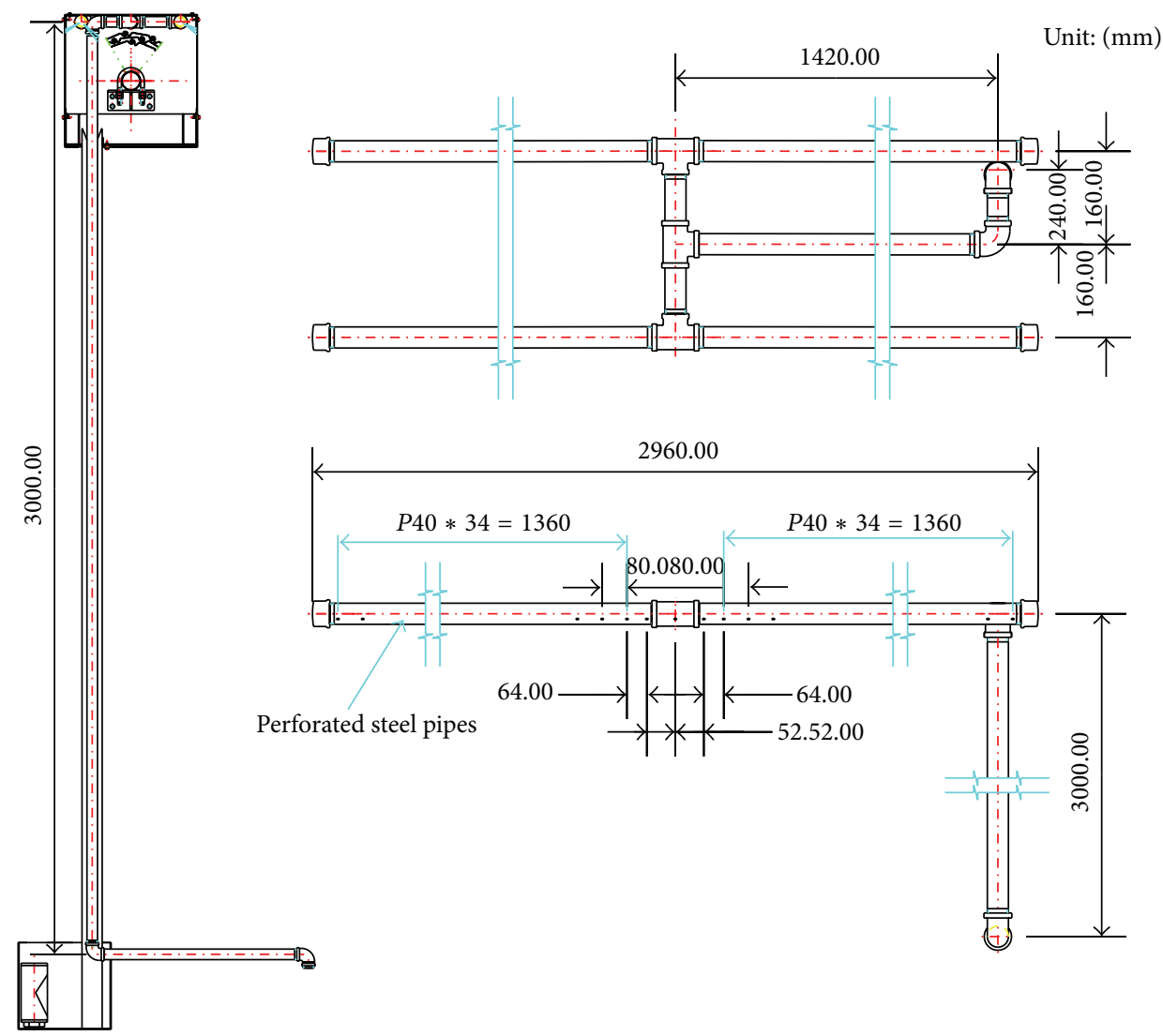

Figure 7: Perforated steel pipes and piping system. 


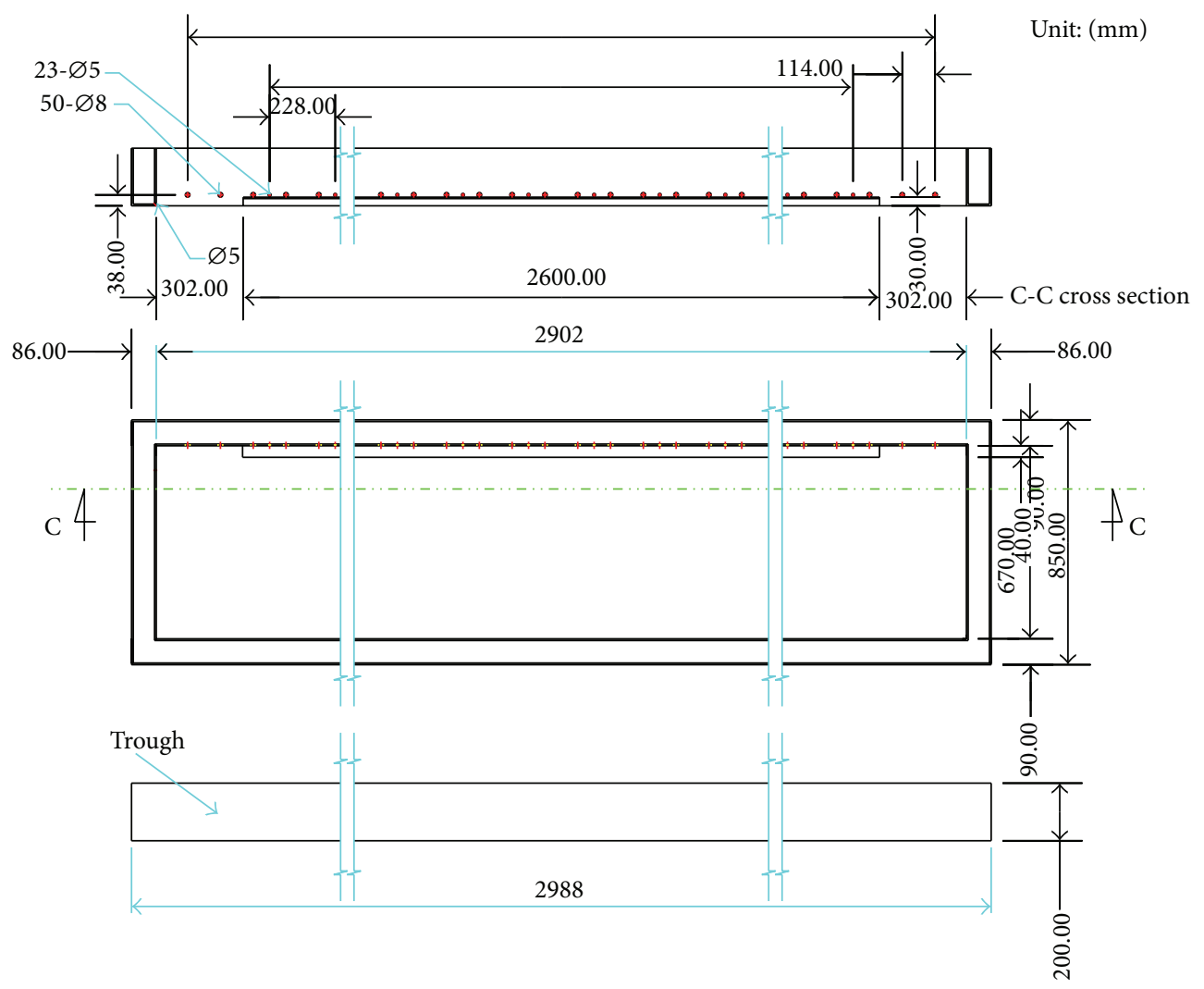

FIGURE 8: Trough in the space between the roller box surfaces and baffle board.

provide stable water film on the unexposed surface, the heat is removed by the heat convection of water film and water film vaporization, and the unexposed surface temperature can be kept at about $100^{\circ} \mathrm{C}$, so that the thermal radiation of unexposed surface is reduced greatly, and the safety of unexposed surface is enhanced. For the overall average temperature curve of each location, as shown in Figure 10, the maximum value of average temperature is about $100^{\circ} \mathrm{C}$, which is far below $170^{\circ} \mathrm{C}$, the average temperature limit of the shutter slat surface set in CNS 14803. Besides, the maximum value of every temperature curve is lower than $210^{\circ} \mathrm{C}$, the max temperature limit of the shutter slat surface set in CNS 14803. It indicates that the proposed design forms a stable and water film with uniform thickness that covers the shutter slats, resulting in good heat resistance.

Table 1 shows the heating test record of water film on unexposed surface. The water circulation system is switched on 30 seconds before the test, the initial upwarp of roller door is $0 \mathrm{~cm}$, and the roller door upwarp is recorded at 0,60 , and $120 \mathrm{~min}$ in the test process. There are pumping failure $\left(27^{\prime} 58^{\prime \prime}\right)$ and water film system dropout $\left(49^{\prime} 00^{\prime \prime}\right)$ in the test process, but they are repaired in time; the test is not influenced. According to the record, (a) no penetration of flame and any penetration-through crack, gap or hole recognized to cause the failure of integrity; (b) no sustained flaming on the unexposed surface of specimen; (c) the upwarp of roller door bottom bed plate is kept at $0 \mathrm{~cm}$ at
0, 60, and 120 min during heating test period; and (d) no roller shutter derailed. Therefore, the roller door specimen with water film on the exposed surface has the flame retardant performance in the heating test specified by CNS 14803 [5].

3.2. Heat Resistance Enhancement of Water Film on Exposed Surface. Figure 11 shows the temperature variations of each thermocouple in the interior of the furnace for the fire test along with the standard temperature curve of CNS 14803. The comparison between the curve of average temperature inside furnace and standard heating temperature curve indicates that, within 75 minutes of heating, the average temperature inside furnace is in the standard temperature interval (standard temperature $\pm 100^{\circ} \mathrm{C}$ ). However, after 75 minutes, it goes below the lower limit of standard temperature curve. It was not the operating mistake of less fuel supply. The temperature difference continues in increasing due to the absorption of heat by water film evaporation and the gradual accumulation of steam, which also continuously absorb the heat inside the refractory furnace. The maximum average furnace temperature in the test is approximately $900^{\circ} \mathrm{C}$. Figure 12 shows the temperature time curve of unexposed surface (surface without water film). The temperatures at various points basically rise with the temperature inside furnace (Figure 11). The average temperature shows that from the beginning of heating to 35 minutes, the unexposed surface temperature rises continuously; from $35 \mathrm{~min}$ of heating test 
TABLE 1: Heating test record of high-speed roller door with water film on unexposed surface.

\begin{tabular}{|c|c|}
\hline \multicolumn{2}{|r|}{ Exposed surface: water film on the unexposed surface } \\
\hline Date of test: February 13, 2014 & $\begin{array}{l}\text { Indoor temperature: } 20^{\circ} \mathrm{C} \\
\text { Indoor humidity: } 61 \%\end{array}$ \\
\hline Heating test duration (h:m:s) & Test observations \\
\hline $0: 00:-30$ & Switch on water circulation system 30 seconds before heating \\
\hline 0:00:00 & Heating begins (roller door upwarp of roller door bottom bed plate is $0 \mathrm{~cm}$ ) \\
\hline $0: 27: 00$ & Supplement tap water \\
\hline $0: 27: 58$ & Water circulation system pumping failure \\
\hline 0:49:00 & Water supply system drops out, repaired instantly \\
\hline 1:00:00 & Roller door upwarp is $0 \mathrm{~cm}$ \\
\hline $1: 48: 40$ & $\begin{array}{l}\text { Temperature measured by handheld thermocouple at unexposed surface measuring point TC\#_8 } \\
\text { is } 67^{\circ} \mathrm{C}\end{array}$ \\
\hline 1:50:10 & $\begin{array}{l}\text { Temperature measured by handheld thermocouple at unexposed surface measuring point TC\#_3 } \\
\text { is } 97^{\circ} \mathrm{C}\end{array}$ \\
\hline 1:51:30 & $\begin{array}{l}\text { Temperature measured by handheld thermocouple at unexposed surface measuring point TC\#_9 } \\
\text { is } 99^{\circ} \mathrm{C}\end{array}$ \\
\hline 1:53:10 & $\begin{array}{l}\text { Temperature measured by handheld thermocouple at unexposed surface measuring point TC\#_5 } \\
\text { is } 110.7^{\circ} \mathrm{C}\end{array}$ \\
\hline 1:55:00 & $\begin{array}{l}\text { Temperature measured by handheld thermocouple at unexposed surface measuring point TC\#_6 } \\
\text { is } 84.1^{\circ} \mathrm{C}\end{array}$ \\
\hline 2:00:00 & Stop heating; roller door upwarp is $0 \mathrm{~cm}$, not exceeding $1.91 \mathrm{~cm}$ \\
\hline
\end{tabular}

to the end of experiment, the average temperature is about $80^{\circ} \mathrm{C}$.

Table 2 shows the heating test record of water film on exposed surface. The water circulation system is switched on 30 seconds before test, the initial upwarp of roller door is $0 \mathrm{~cm}$, and the upwarp of roller door is recorded at 0,60 , and $120 \mathrm{~min}$ in the test process. According to the record, (a) no penetration of flame and any penetration-through crack, gap or hole recognized to cause the failure of integrity; (b) no sustained flaming on the unexposed surface of specimen; (c) the upwarp of roller door bottom bed plate is kept at $0 \mathrm{~cm}$ at 0,60 , and $120 \mathrm{~min}$ in the heating test; and (d) no roller shutter derailed. Therefore, the roller door specimen with water film on the exposed surface has the flame retardant performance in the heating test specified by CNS 14803 [5].

3.3. Discussion about Water Film on Exposed Surface and Unexposed Surface. According to the experimental results of water film system on exposed surface and unexposed surface, the fireproof characteristics of the roller door with water film system are described below:

(1) When the water film is on exposed surface, the combustion furnace temperature rises slowly after 20 minutes. When the water film is on unexposed surface, the temperature inside furnace rises steadily before 60 minutes, and because the heat inside the combustion furnace is absorbed by water evaporation directly, the furnace temperature of water film on exposed surface is lower than that of water film on unexposed surface. This result also shows that if the water film is on exposed surface, it works like as a sprinkler, reducing the fire scene temperature to avoid flashover.

(2) According to the consumption of fuel, when the water film is on unexposed surface, the LPG consumption is $510.4 \mathrm{~m}^{3}$ in two hours; when the water film is on exposed surface, the LPG consumption is $530.4 \mathrm{~m}^{3}$ in two hours; the difference between the two combustion heat values is $1880 \mathrm{MJ}$. The result means when the water film is on the fire side, the heat resistance can be maintained for two hours under higher fire load.

(3) Different water replenishing control modes are used for the two experiments. For the water film on unexposed surface, the water replenishing valve is turned on when the water level of the water storage tank is lower than $2 / 3$ of height; for the water film on exposed surface, the water replenishing valve is turned on when the water temperature of water storage tank is higher than $80^{\circ} \mathrm{C}$. After two hours of experiment, the water film on unexposed surface is replenished with $2000 \mathrm{~L}$ water, and the water film on exposed surface is replenished with $2660 \mathrm{~L}$ water. The experimental results show that the water supply temperature may be high when the water replenishing timing is controlled by water level, and the water film absorbs heat until the heat is transferred to the shutters, so the shutter temperature of water film on unexposed surface is higher than that of water film on exposed surface. The experimental result of water film on exposed surface shows that as the amount of water film evaporated by high temperature inside the furnace must be greater than the evaporation capacity 
TABLE 2: Heating test record of high-speed roller door with water film on exposed surface.

\begin{tabular}{|c|c|}
\hline \multicolumn{2}{|r|}{ Exposed surface: water film on the exposed surface } \\
\hline Date of test: May 22, 2014 & $\begin{array}{c}\text { Indoor temperature: } 32.4^{\circ} \mathrm{C} \\
\text { Indoor humidity: } 63 \%\end{array}$ \\
\hline Heating test duration (h:m:s) & Test observations \\
\hline 0:00:-30 & Switch on water circulation system 30 seconds before heating \\
\hline 0:00:00 & Heating begins (roller door upwarp of roller door bottom bed plate is $0 \mathrm{~cm}$ ) \\
\hline 0:20:00 & Fill $200 \mathrm{~L}$ water in water tank \\
\hline $0: 27: 40$ & $\begin{array}{l}\text { Temperature measured by handheld thermocouple at unexposed surface measuring point TC\#_99 } \\
\text { is } 51^{\circ} \mathrm{C}\end{array}$ \\
\hline $0: 29: 53$ & $\begin{array}{l}\text { Temperature measured by handheld thermocouple at unexposed surface measuring point TC\#_7 } \\
\text { is } 50^{\circ} \mathrm{C}\end{array}$ \\
\hline 0:30:00 & Fill $240 \mathrm{~L}$ water in water tank \\
\hline 0:43:00 & Fill $260 \mathrm{~L}$ water in water tank \\
\hline 0:50:00 & Fill $280 \mathrm{~L}$ water in water tank \\
\hline 0:55:00 & Roller door upwarp is $0 \mathrm{~cm}$ \\
\hline 0:59:00 & $\begin{array}{l}\text { Temperature measured by handheld thermocouple at unexposed surface measuring point TC\#_7 } \\
\text { is } 55.9^{\circ} \mathrm{C}\end{array}$ \\
\hline 0:59:50 & $\begin{array}{l}\text { Temperature measured by handheld thermocouple at unexposed surface measuring point TC\#_9 } \\
\text { is } 60.6^{\circ} \mathrm{C}\end{array}$ \\
\hline 1:00:00 & Fill $320 \mathrm{~L}$ water in water tank \\
\hline $1: 10: 00$ & Fill $340 \mathrm{~L}$ water in water tank \\
\hline 1:20:00 & Fill $280 \mathrm{~L}$ water in water tank \\
\hline $1: 25: 50$ & $\begin{array}{l}\text { Temperature measured by handheld thermocouple at unexposed surface measuring point TC\#_7 } \\
\text { is } 68.4^{\circ} \mathrm{C}\end{array}$ \\
\hline $1: 26: 30$ & $\begin{array}{l}\text { Temperature measured by handheld thermocouple at unexposed surface measuring point TC\#_9 } \\
\text { is } 61.3^{\circ} \mathrm{C}\end{array}$ \\
\hline $1: 30: 00$ & Fill $260 \mathrm{~L}$ water in water tank \\
\hline 1:40:00 & Fill $260 \mathrm{~L}$ water in water tank \\
\hline 1:50:00 & Fill $220 \mathrm{~L}$ water in water tank \\
\hline 1:52:00 & $\begin{array}{l}\text { Temperature measured by handheld thermocouple at unexposed surface measuring point TC\#_8 } \\
\text { is } 79.5^{\circ} \mathrm{C}\end{array}$ \\
\hline 1:53:00 & $\begin{array}{l}\text { Temperature measured by handheld thermocouple at unexposed surface measuring point TC\#_7 } \\
\text { is } 70.2^{\circ} \mathrm{C}\end{array}$ \\
\hline 1:54:00 & $\begin{array}{l}\text { Temperature measured by handheld thermocouple at unexposed surface measuring point TC\#_9 } \\
\text { is } 59.6^{\circ} \mathrm{C}\end{array}$ \\
\hline 2:00:00 & Stop heating; roller door upwarp is $0 \mathrm{~cm}$, not exceeding $1.91 \mathrm{~cm}$ \\
\hline
\end{tabular}

of water film on unexposed surface, the required water supply is $660 \mathrm{~L}$ more than the water film on unexposed surface.

(4) After two-hour heating test, the impact test was then carried out three times for the specimen within 30 minutes after heating test based on CNS 14803. Figure 13 indicated that the specimen was not damaged; there is no penetration-through crack or no shutter derailed. Therefore, the specimens with water film on exposed surface and unexposed surface passed the impact test, respectively.

\section{Conclusions}

This study designed the water circulating device of water film system. The full-scale door/wall refractory test was conducted to investigate the fire resistance of the high-speed roller door with water film system, proving that this roller door has $120 \mathrm{~A}$ fire endurance. Based on the experimental results obtained, the following conclusions can be drawn up.

(1) Water circulating device of water film system: the water film flows into the water reservoir, and the pumping pump delivers water to the water storage 


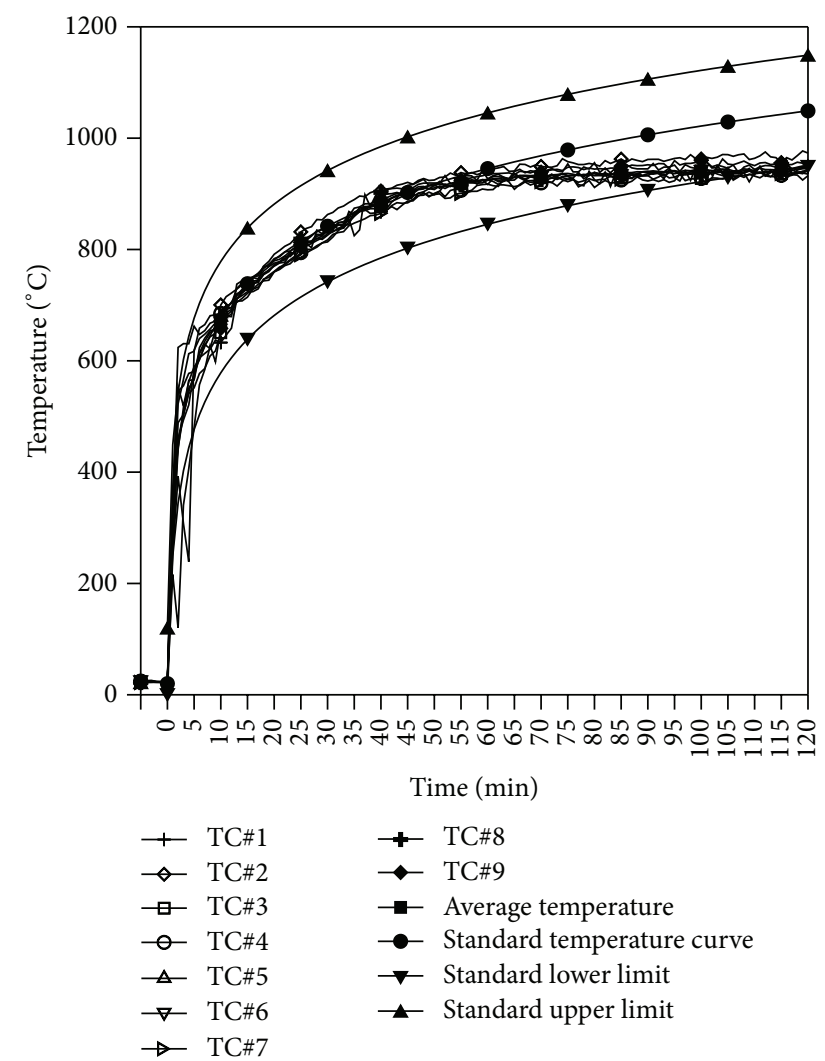

FIGURE 9: Temperature distributions of the interior furnace (water film on the unexposed surface).

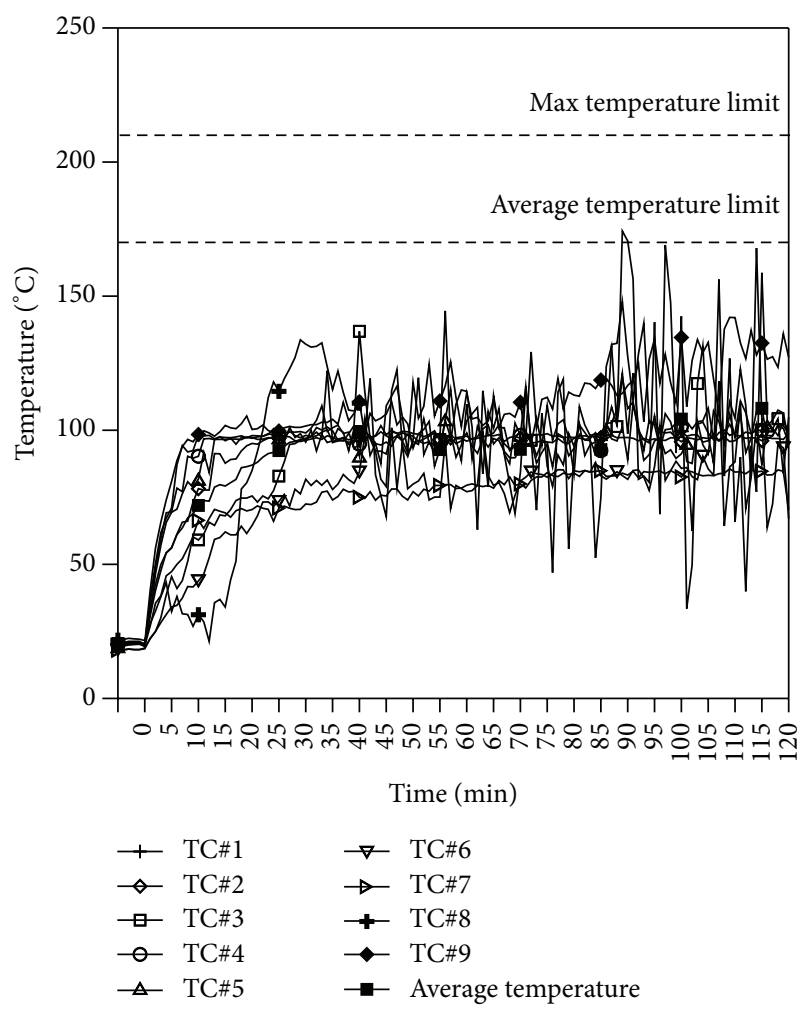

Figure 10: Temperature distributions of the unexposed surface (water film on the unexposed surface).

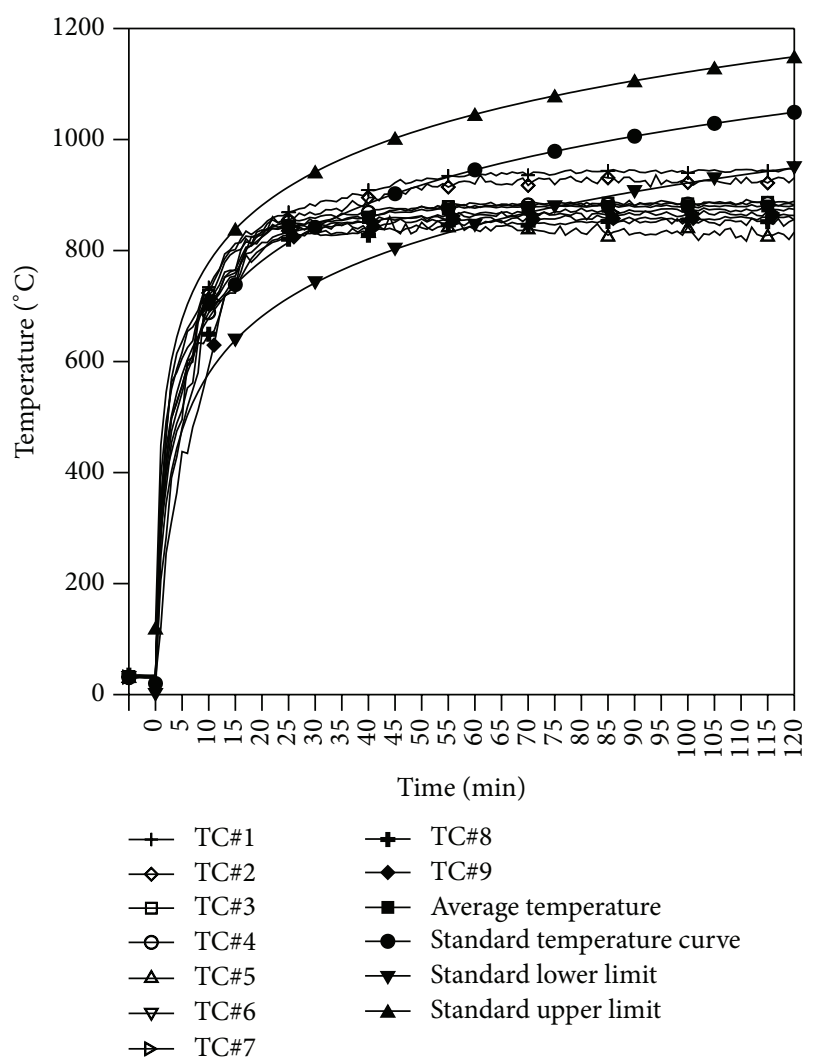

FIGURE 11: Temperature distributions of the interior furnace (water film on the exposed surface).

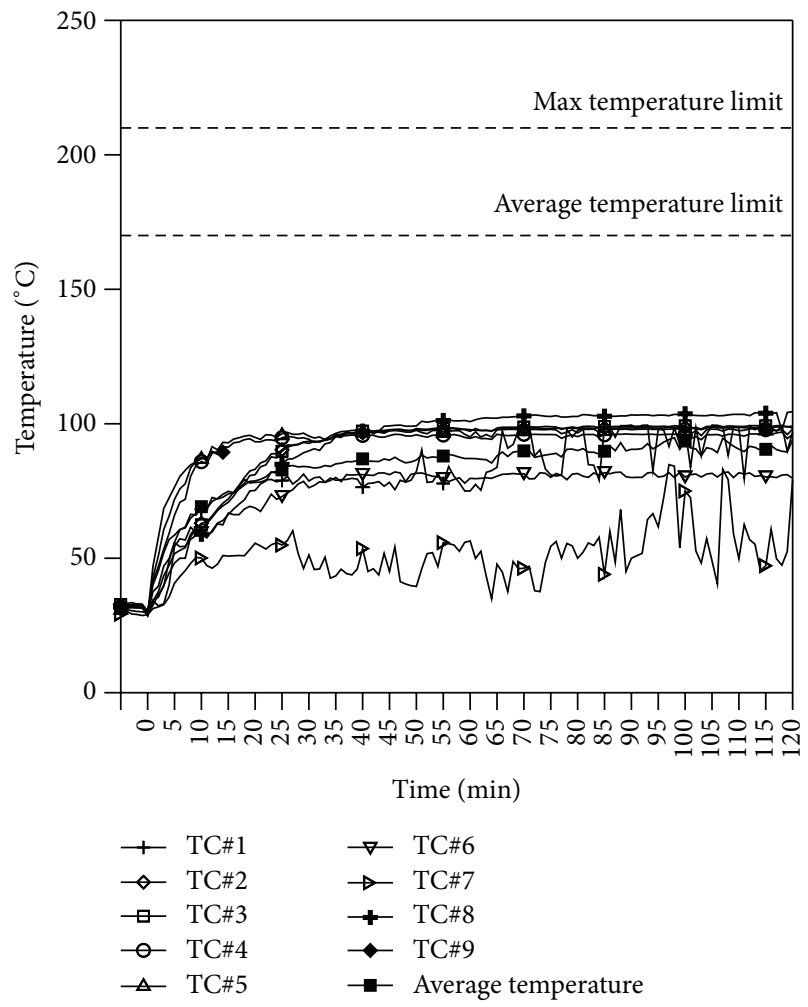

FIGURE 12: Temperature distributions of the unexposed surface (water film on the exposed surface). 


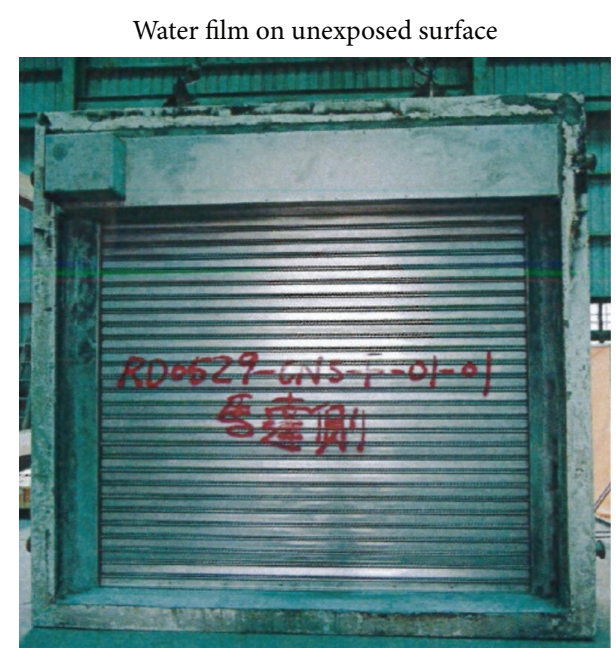

Exposed surface before test (the side of roller box)

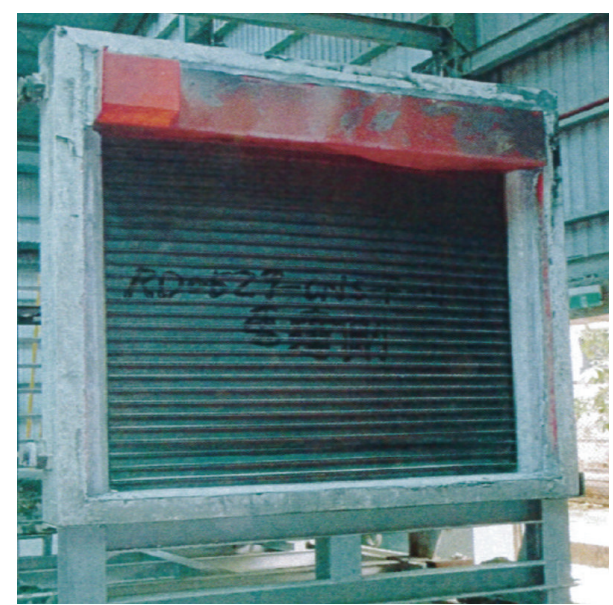

Exposed surface at $60 \mathrm{mins}$

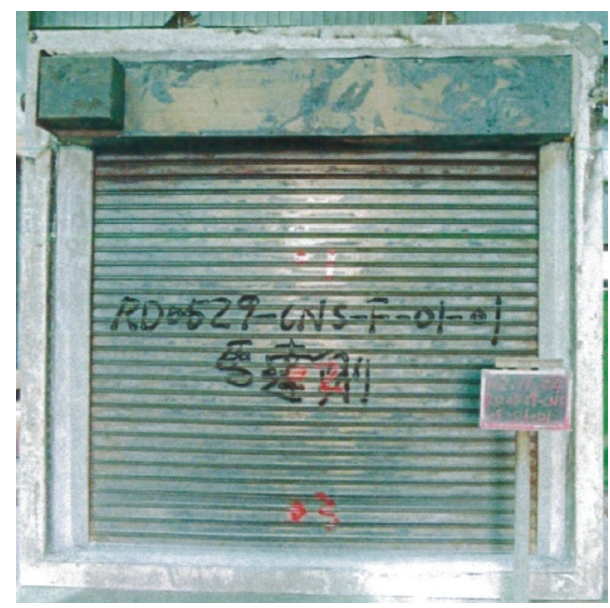

Exposed surface after impact test
Water film on exposed surface

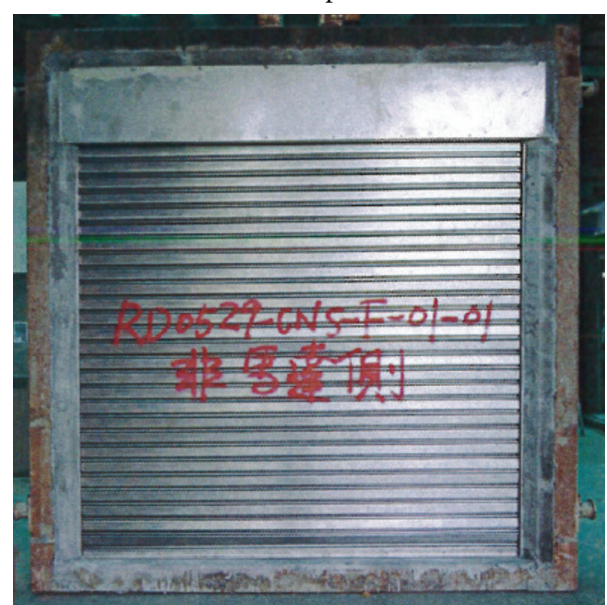

Exposed surface before test (not the side of roller box)

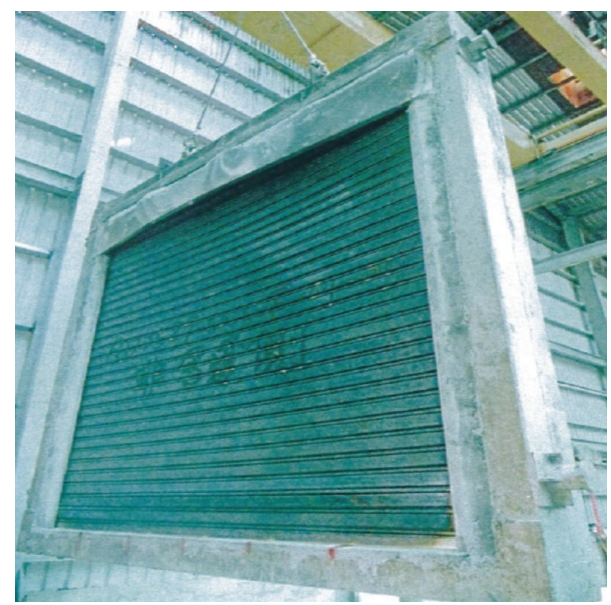

Exposed surface at $60 \mathrm{mins}$

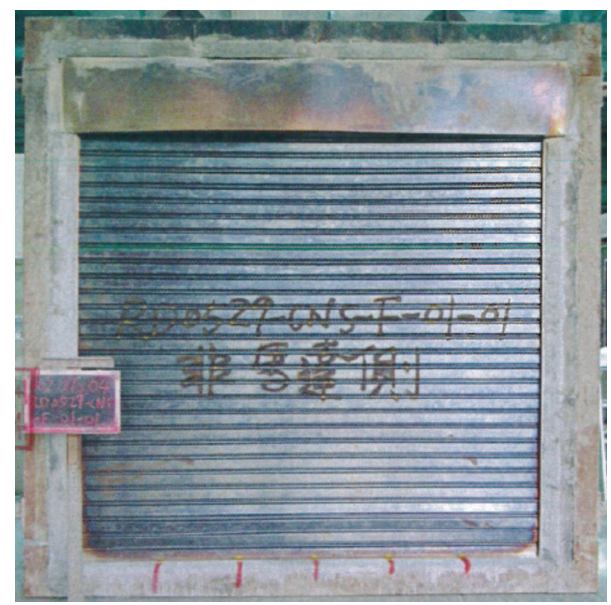

Exposed surface after impact test

FIgURE 13: Exposed surface before heating test, at $60 \mathrm{mins}$, and after impact test with water film on exposed/unexposed surface.

tank. The water supply pump injects water into the perforated pipe to spray water film, forming recycling. This device can reduce the water consumption during a fire.
(2) Fire resistance test: in the fire test, the LPG fuel consumption in the case of water film on exposed surface is higher than that in the case of water film on unexposed surface, but the furnace temperature in 
the case of water film on exposed surface is lower. It implies that when the water film is on the exposed side, the heat resistance performance of roller door can be maintained for two hours under higher fire load, and the fire scene temperature is reduced to avoid flashover. The water consumption of water film on exposed surface is higher than the water film on unexposed surface by 660 L. Furthermore, no matter which side of this high-speed roller shutter is exposed to fire, a 120A fire resistance rating can be achieved by the proposed water film system in this study.

\section{Conflict of Interests}

The authors declare that there is no conflict of interests regarding the publication of this paper.

\section{Acknowledgments}

This study was supported by the Ministry of Science and Technology, China. for financial support under Projects NSC 102-2622-E-006-023-CC2. The authors also thank Nagaoka Machinery Co., Ltd. for their assistance on the sample tests.

\section{References}

[1] Wikipedia, "Geography of Taiwan," http://en.wikipedia.org/ wiki/Geography_of_Taiwan.

[2] Typhoon Database, (Chinese), http://rdc28.cwb.gov.tw/TDB/ ntdb/pageControl/ty_warning.

[3] Building Design Construction Section no.79, Building Technical Rules, Taiwan, 2010.

[4] Y.-J. Chuang, Y.-H. Chuang, and C.-Y. Lin, "Fire tests to study heat insulation scenario of galvanized rolling shutters sprayed with intumescent coatings," Materials and Design, vol. 30, no. 7, pp. 2576-2583, 2009.

[5] CNS 14803, Method of fire resistance test for rolling shutter of buildings, Taiwan (ROC), 2002.

[6] T. Aihara, M. Taga, and T. Haraguchi, "Heat transfer from a uniform heat flux wedge in air-water mist flows," International Journal of Heat and Mass Transfer, vol. 22, no. 1, pp. 51-60, 1979.

[7] J. K. Richardson and I. Oleszkiewicz, "Fire tests on window assemblies protected by automatic sprinklers," Fire Technology, vol. 23, no. 2, pp. 115-132, 1987.

[8] S. Nishio and Y.-C. Kim, "Heat transfer of dilute spray impinging on hot surface (simple model focusing on rebound motion and sensible heat of droplets)," International Journal of Heat and Mass Transfer, vol. 41, no. 24, pp. 4113-4119, 1998.

[9] N. Sozbir, Y. W. Chang, and S. C. Yao, "Heat transfer of impacting water mist on high temperature metal surfaces," Journal of Heat Transfer, vol. 125, no. 1, pp. 70-74, 2003.

[10] Z. G. Cai, H. L. Li, L. Y. Chen, B. Cai, G. X. Liao, and L. G. Shen, "Experimental studies on flow field diagnosis and thermal radiation blockage of water curtain," Fire Safety Science, vol. 13, no. 4, pp. 224-230, 2004.

[11] C.-W. Wu, T.-H. Lin, M.-Y. Lei, T.-H. Chung, C.-C. Huang, and W.-T. Chiang, "Fire test on a non-heat-resistant fireproof glass with down-flowing water film," in Proceedings of the 8th International Symposium on Fire Safety Science ( IAFSS '05), pp. 327-338, Beijing, China, September 2005.
[12] C. W. Wu and T. H. Lin, "Fire resistance tests of a glass pane with down-flowing water film," Tech. Rep., Safety Technology, Taipei, Taiwan, 2005.

[13] J. Wendelstorf, K.-H. Spitzer, and R. Wendelstorf, "Spray water cooling heat transfer at high temperatures and liquid mass fluxes," International Journal of Heat and Mass Transfer, vol. 51, no. 19-20, pp. 4902-4910, 2008.

[14] H.-T. Chen and S.-K. Lee, "Estimation of heat-transfer characteristics on the hot surface of glass pane with down-flowing water film," Building and Environment, vol. 45, no. 10, pp. 20892099, 2010.

[15] Latent heat, https://en.wikipedia.org/wiki/Latent_heat.

[16] B. P. Husted, G. Holmstedt, and T. Hertzberg, "The physics behind water mist systems," in Proceedings of the 15th International Water Mist Conference (IWMA '04), Rome, Italy, 2004.

[17] Water Mist Fire Suppression, http://www.aqteq.com/5255 .html? CID=1.

[18] H. Y. Chen, C. H. Wang, and P. L. Fan, "Water sprinkling protection of fire control curtain," Water \& Wastewater Engineering, vol. 30, no. 7, pp. 74-76, 2004 (Chinese).

[19] Y. Liu, C. Y. Yuan, and Y. C. Pai, "On design parameters of fine spraying rolling screen system for fire control," Science and Technology of Overseas Building Materials, vol. 26, no. 4, pp. 8589, 2005 (Chinese).

[20] Y. Feng, M. F. Huang, and Y. R. Zhong, "Study on the interaction of mist water spray with fire-resisting rolling shutter," Manufacturing Automation, vol. 30, pp. 84-87, 2008.

[21] C. Y. Lin, Heat resistance of steel roller shutter covered by water film [M.S. thesis], National Cheng Kung University, Tainan, Taiwan, 2004.

[22] D. N. Priest, How Accurate Are Those Thermocouples? Priest \& Associates Consulting, 2007.

[23] T. H. Chung, T. H. Lin, M. Y. Lei, C. C. Huang, and W. T. Chang, "Flameproof water-flow producer," Taiwan Patent, TW I286080.

[24] D. H. Lin, M. J. He, and R. L. Chen, "Multi-hollowed pipe water film generation device for flame-proof," Taiwan patent, TW 201307666, 2011.

[25] S.-K. Lee, M.-C. Ho, J.-J. Chen, C.-Y. Lin, and T.-H. Lin, "Fire resistance evaluation of a steel roller shutter with water-film cooling system," Applied Thermal Engineering, vol. 58, no. 1-2, pp. $465-478,2013$. 

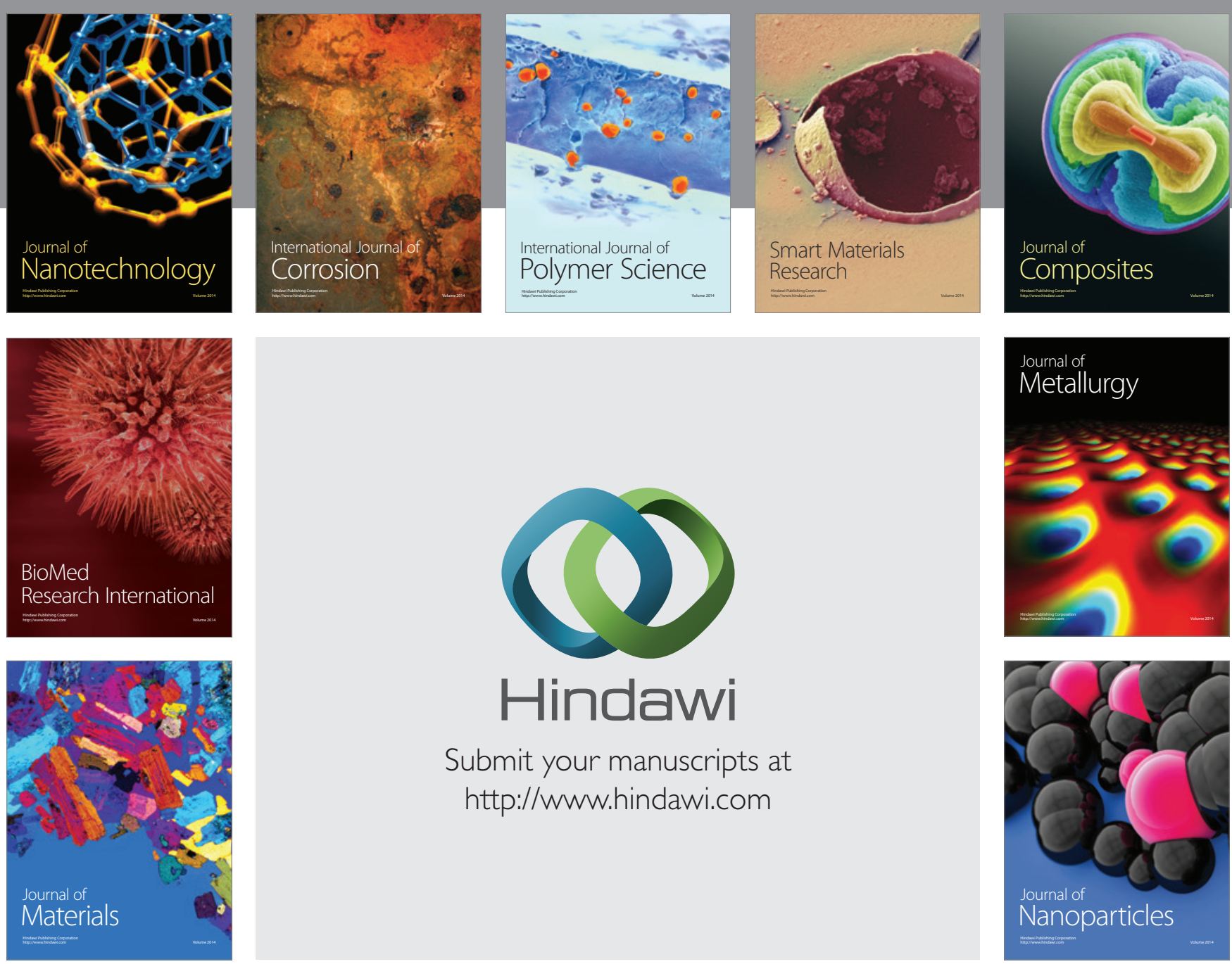

Submit your manuscripts at http://www.hindawi.com
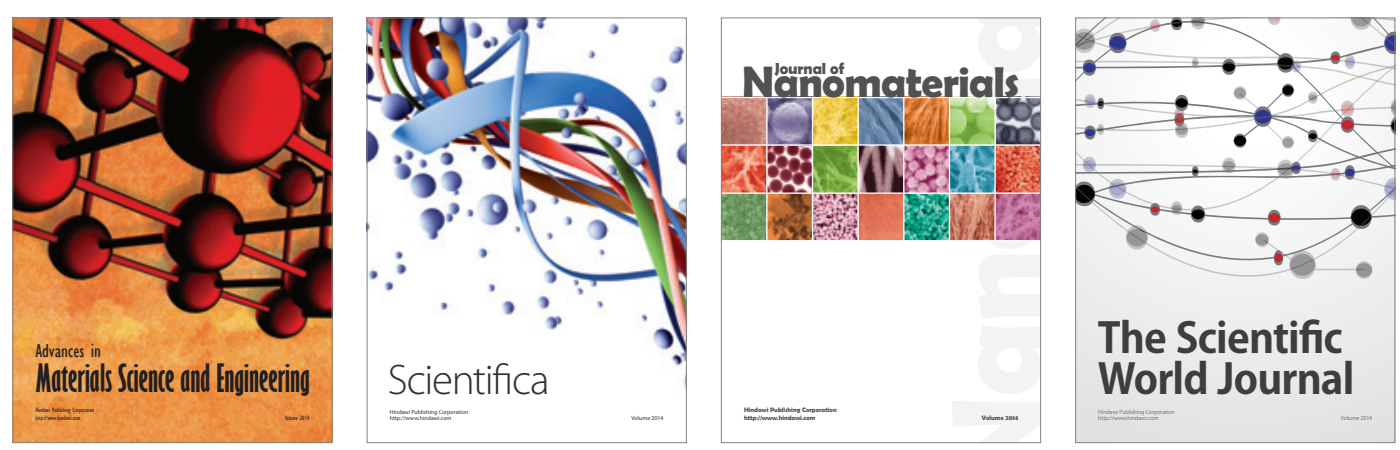

\section{The Scientific World Journal}
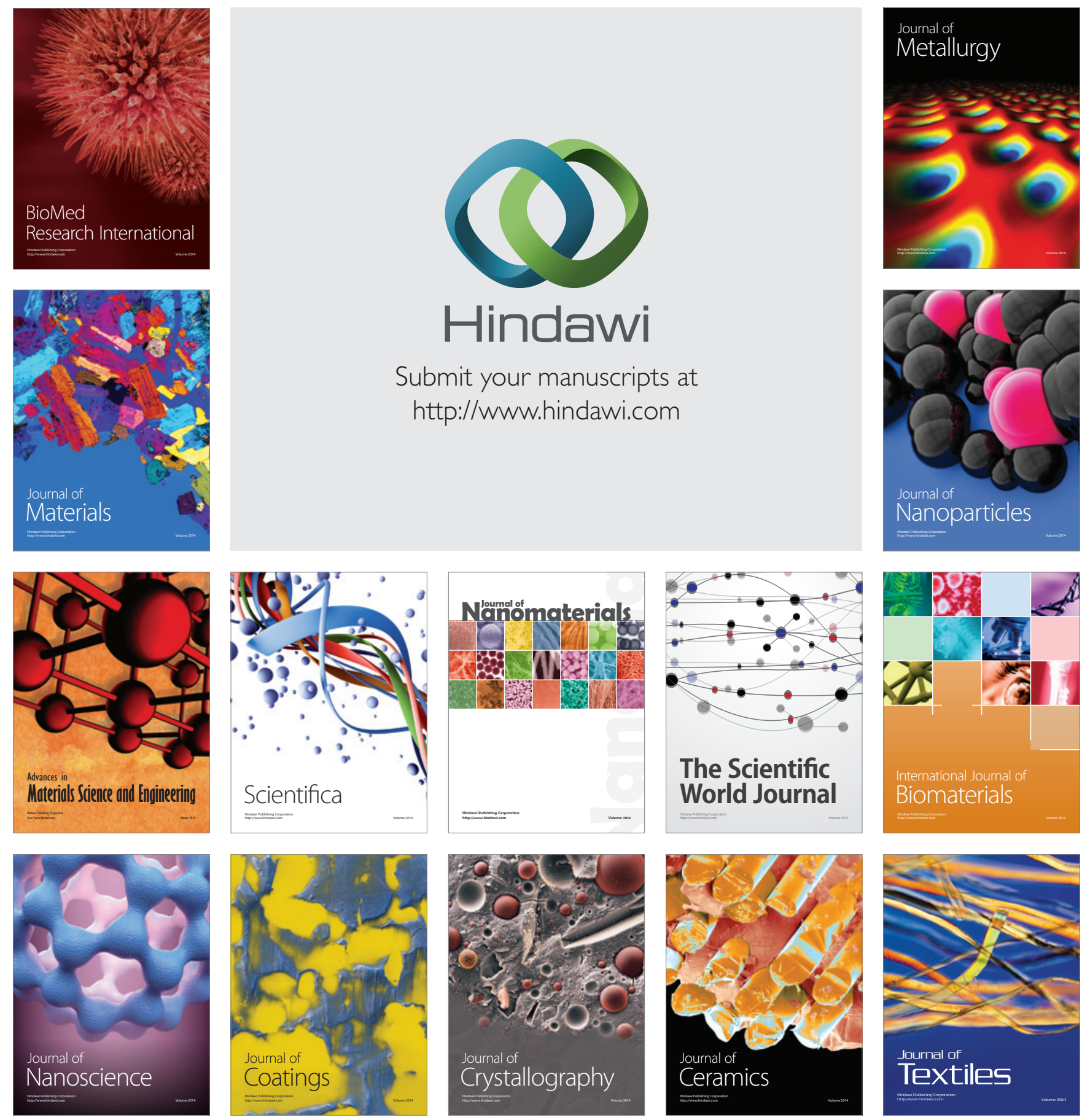